\title{
Performance and Variability Evaluation in Some Genotypes of Winged Bean [Psophocarpus tetragonolobus (L.) DC.]
}

\author{
Achal Kant* and Rajeshwar Nandan
}

Department of Genetics and Plant Breeding, Institute of Agricultural Sciences, Banaras Hindu University, Varanasi-221005, U.P., India

*Corresponding author

\section{A B S T R A C T}

\begin{tabular}{|l|}
\hline Ke y w o r d s \\
Winged bean, \\
Ambika WB-13-6, \\
Genotypes, Seed \\
yield
\end{tabular}

\section{Introduction}

Winged bean [Psophocarpus tetragonolobus (L.) DC.], self-fertilizing leguminous crop and have diploid chromosome number is $2 \mathrm{n}=2 \mathrm{x}=$ 18/22 (NAS, 1981; Mohanty et al., 2013).

It is also called as Goa bean, four angled bean, choughula sem, chara konisem, God-sent vegetable and princess pea, has assumed considerable importance at present as a protein rich multipurpose crop (Amoo et al., 2006; Ray et al., 2012).Winged bean evolved in
Winged bean is a multipurpose underutilised legume. It is consumed as leaves, flowers, pods, seeds and also tuberous roots because of their great nutritional values. The present investigation was carried out on performance and variability evaluation for seed Characters and flower colour among 27 genotypes of winged bean. The research trial was conducted at Vegetable Research Farm of Banaras Hindu University, Varanasi, Uttar Pradesh during kharif season of 2014-2015.Based on different characters, the genotype Ambika WB-13-6 exhibited highest mean performance for seed yield per plant (31.96 gm), mature pod length $(17.44 \mathrm{~cm}$.), mature pod width $(2.11 \mathrm{~cm}$.) and no. of seeds per pod(13.67) with 70 days $50 \%$ flowering as well as average leaf area index at 50\% flowering (1.35) followed by RWB-13, EC-27884, EC-17830 and RWB-15 which appeared promising for different characters. Therefore, Ambika WB-13-6 along with the above four genotypes could be tested under different agronomic practices for commercial production and human consumption of this underutilized legume. Creamy white colour, black colour and brown colour types of seed coat as well as white and violet types flower were founded and indicated variation among 27 genotypes of winged bean. 
All parts of winged bean are rich in protein, vitamins and minerals (Chandel et al., 1978a; Mahto and Dua, 2009). It is an underutilized legume; very little research work has been done on its genetic improvement.

The knowledge on genetic variability in the available accessions is a prerequisite for effective selection of superior genotypes. Therefore, realizing the importance and need of this legume present investigation was undertaken with the objective to mean performance and variability evaluation in 27 genotypes of winged bean.

\section{Materials and Methods}

Twenty seven winged bean genotypes were collected from Birsa agriculture university, Ranchi and Banaras Hindu University were used for the present study (Table 1). The genotypes were evaluated at the vegetable research farm, Institute of Agricultural Sciences, Banaras Hindu University (U.P.) during the summer season 2014-2015. The experimental site was located at $25.26^{\circ} \mathrm{N}$ latitude and $82.99^{\circ} \mathrm{E}$ longitude at an altitude of $87 \mathrm{~m}$ above mean sea level.

The experiment was conducted in a Randomized block design with three replications during kharif season 2014-15. Each genotype was sown in single row plots. Each plot was consisted of one row of $5 \mathrm{~m}$, length with $75 \mathrm{~cm}$, row to row and $25 \mathrm{~cm}$, plant to plant distance.

Recommended agronomic practices were followed to raise the healthy crop. Observations on six yield attributing traits viz., days to $50 \%$ flowering, LAI at $50 \%$ flowering, mature pod length $(\mathrm{cm}$.), Mature pod width $(\mathrm{cm}$.$) , no. of seeds per pod, Seed$ yield per plant (g) were taken on five competitive plants from each replication of genotype under study.

\section{Results and Discussion}

The result of 27 winged bean genotypes showed the range of mean from 65.67 days in Ambika-13-5 to 81.89days in IC-26945 for days to 50\% flowering, 0.63 in Ambika WB 11-3 to 1.61 in RWB-15 for LAI at $50 \%$ flowering, $13.02 \mathrm{~cm}$. in Ambika WB-11-2 (white) to $17.44 \mathrm{~cm}$. in Ambika WB -13-6 for mature pod length, $1.46 \mathrm{~cm}$. in Ambika WB$11-3$ to $2.16 \mathrm{~cm}$. in EC-27884 for mature pod width, 7.33 in RMDWB-1 to 13.67 in Ambika WB-13-6for no. of seeds per pod, $15.76 \mathrm{~g}$ in RMDWB-1 to $31.96 \mathrm{~g}$ in Ambika WB-13-6 for seed yield per plant.

The upper limit of range for various traits under study was exhibited by different genotypes. However, genotype exhibiting highest values for more than one characters are Ambika WB-13-6 for seed yield per plant $(31.96 \mathrm{~g})$, mature pod length $(17.44 \mathrm{~cm})$, no. of seeds per pod (13.67), mature pod width (2.11 $\mathrm{cm}$.), LAI at $50 \%$ flowering (1.35) with 66 days to $50 \%$ flowering followed by RWB-13, EC-27884, EC-17830 and RWB-15 which appeared promising for different characters (Table 1 and Fig. 1).

Based on mean variability in related traits under study was also reported by previous scientists (Chandel et al., 1984; Philip and Ramachandran, 1986; Seth et al., 1988; Singh and Khanna, 1995; Mohamadali and Madalageri, 2007; Nandan et al., 2010; Ray et al., 2012; Prasanth et al., 2015) in winged bean accessions.

Creamy white Seed coat colour in Ambika WB-11-2 (white), black seed coat colour in EC-178279 and light brown to dark brown seed coat colour in remaining 25genotypes were observed (Fig. 2). White colour flower in Ambika WB-11-2 (white) and violet colour flower in remaining 26 genotypes were observed (Fig. 3). 
Table.1 Range and mean performance of different characters in 27 genotypes of winged bean

\begin{tabular}{|c|c|c|c|c|c|c|c|}
\hline $\begin{array}{c}\text { Serial } \\
\text { no. }\end{array}$ & Characters & $\begin{array}{c}\text { Days to } \\
50 \% \\
\text { flowering }\end{array}$ & $\begin{array}{c}\text { LAI at } \\
50 \% \\
\text { flowering }\end{array}$ & $\begin{array}{c}\text { Mature } \\
\text { pod } \\
\text { length }(\mathrm{cm} .)\end{array}$ & $\begin{array}{l}\text { Mature } \\
\text { pod width } \\
\text { (cm.) }\end{array}$ & $\begin{array}{c}\text { No. Of } \\
\text { seeds } \\
\text { per pod }\end{array}$ & $\begin{array}{c}\text { Seed } \\
\text { yield per } \\
\text { plant }\end{array}$ \\
\hline 1 & Ambika WB-11-1 & 79.18 & 1.03 & 15.04 & 1.80 & 10.03 & 23.49 \\
\hline 2 & Ambika WB-11-2 & 75.33 & 1.58 & 16.08 & 2.02 & 12.22 & 27.65 \\
\hline 3 & Ambika WB-11-2(white) & 74.89 & 0.73 & $13.02 *$ & 1.51 & 8.00 & 19.16 \\
\hline 4 & Ambika WB-11-3 & 72.00 & $0.63 *$ & 14.86 & $1.46 *$ & 8.56 & 23.71 \\
\hline 5 & Ambika WB-13-1 & 67.67 & 1.12 & 16.46 & 1.70 & 13.00 & 29.29 \\
\hline 6 & Ambika -13-5 & $65.67 *$ & 0.91 & 16.11 & 1.63 & 10.56 & 27.93 \\
\hline 7 & Ambika WB-13-6 & 69.89 & 1.35 & $17.44 * *$ & 2.11 & $13.67 * *$ & $31.96 * *$ \\
\hline 8 & Ambika -13-4 & 72.00 & 1.43 & 15.03 & 1.90 & 10.33 & 29.47 \\
\hline 9 & EC-13084 & 80.44 & 1.05 & 14.09 & 1.76 & 8.00 & 16.27 \\
\hline 10 & EC-15018 & 78.89 & 1.12 & 14.58 & 1.49 & 8.33 & 20.21 \\
\hline 11 & EC-27884 & 79.78 & 0.85 & 15.44 & $2.16 * *$ & 10.67 & 31.19 \\
\hline 12 & EC-172600 & 78.67 & 0.88 & 16.42 & 1.88 & 11.22 & 26.76 \\
\hline 13 & EC-178279 & 76.33 & 0.91 & 16.60 & 2.03 & 10.00 & 20.98 \\
\hline 14 & EC-178289 & 77.67 & 0.72 & 13.70 & 1.47 & 7.33 & 17.79 \\
\hline 15 & EC-178295 & 81.78 & 1.00 & 14.64 & 1.68 & 8.33 & 21.91 \\
\hline 16 & EC-178309 & 75.78 & 1.56 & 15.69 & 1.94 & 10.89 & 31.81 \\
\hline 17 & IC-26904 & 72.11 & 0.78 & 14.48 & 2.02 & 8.00 & 17.74 \\
\hline 18 & IC-26945 & 81.89** & 0.72 & 16.82 & 1.53 & 11.11 & 23.06 \\
\hline 19 & IC-38683 & 74.67 & 1.10 & 13.96 & 1.94 & 8.00 & 21.88 \\
\hline 20 & IC-178292 & 72.00 & 1.49 & 15.59 & 1.62 & 10.67 & 28.65 \\
\hline 21 & RMDWB-1 & 79.67 & 0.86 & 14.07 & 1.70 & $7.33 *$ & $15.76 *$ \\
\hline 22 & RWB-2 & 79.22 & 0.95 & 13.98 & 1.51 & 7.67 & 18.35 \\
\hline 23 & RWB-13 & 75.78 & 1.19 & 16.69 & 1.66 & 13.00 & 31.96 \\
\hline 24 & RWB-15 & 73.67 & $1.61 * *$ & 17.27 & 2.10 & 11.67 & 30.01 \\
\hline 25 & RWB-16 & 75.22 & 0.97 & 13.94 & 1.66 & 7.89 & 17.71 \\
\hline 26 & BHW-1 & 78.00 & 1.51 & 15.89 & 1.61 & 11.56 & 29.85 \\
\hline 27 & AKWB-1 & 80.44 & 1.42 & 16.38 & 1.59 & 7.77 & 29.84 \\
\hline \multirow[t]{2}{*}{ Range } & Minimum & 65.67 & 0.63 & 13.02 & 1.46 & 7.33 & 15.76 \\
\hline & Maximum & 81.89 & 1.61 & 17.44 & 2.16 & 13.67 & 31.96 \\
\hline
\end{tabular}
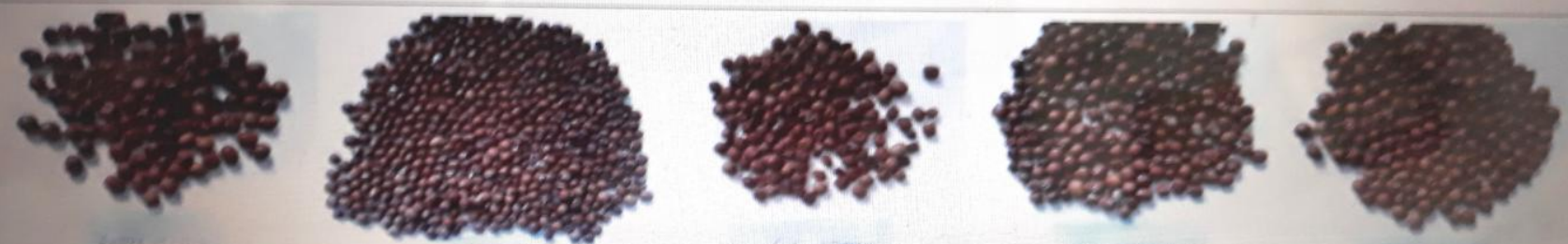

Ambika WB-13-6

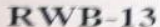

EC-27884

EC-178309

RWB-15

Fig. 1: Based on seed yield per plant for top 5 genotypes among 27 genotypes. 

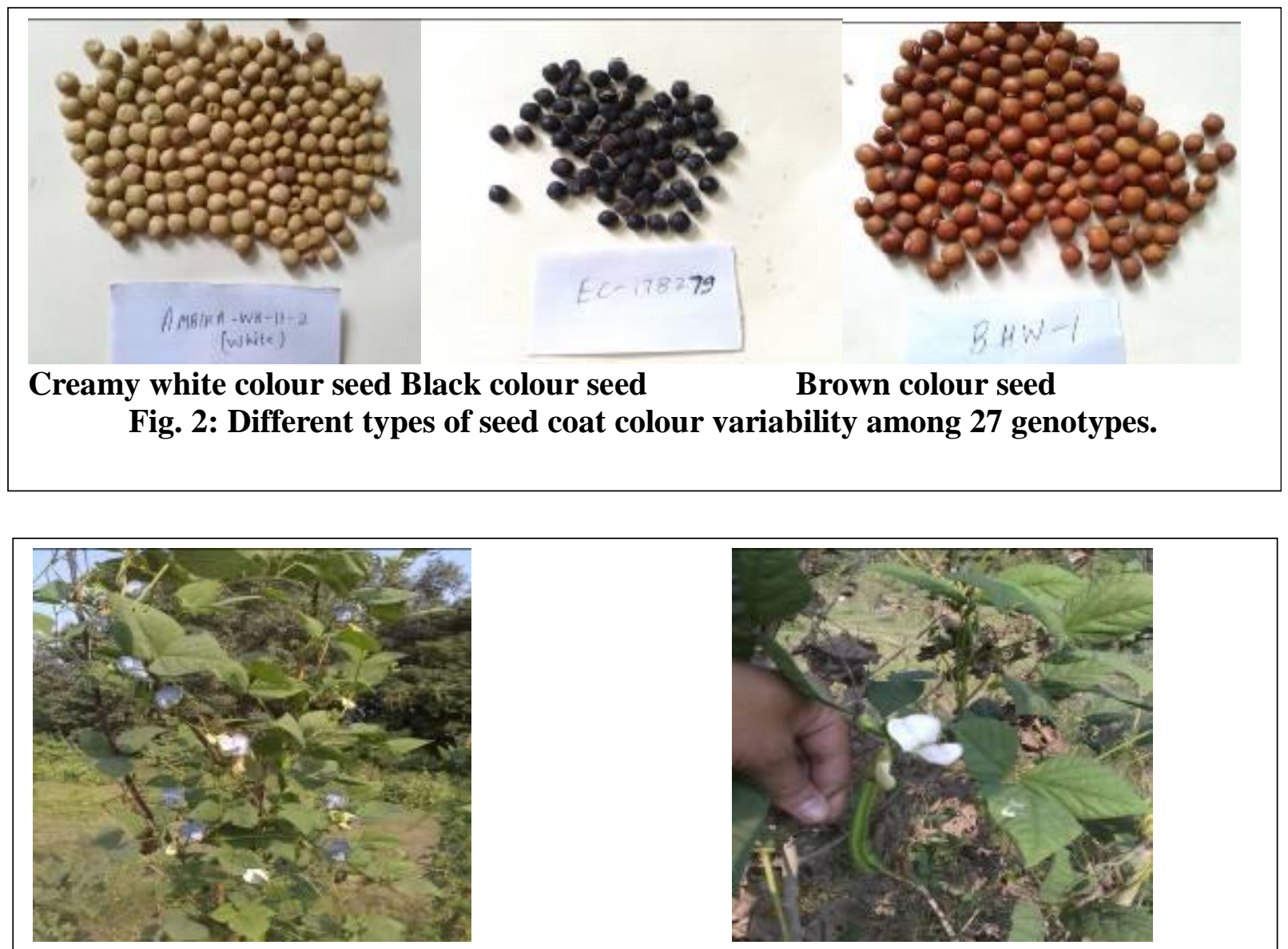

Violet colour flower

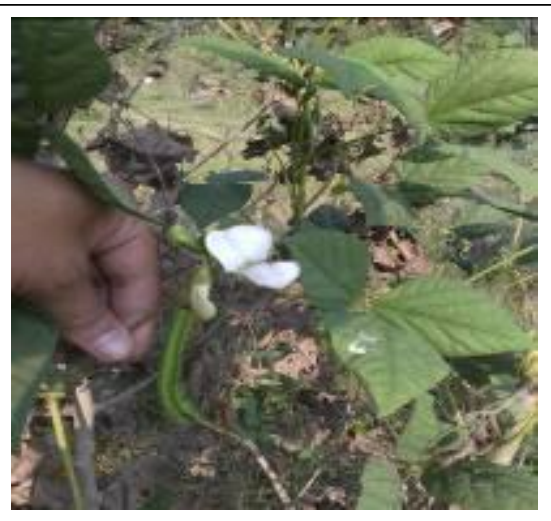

White colour flower

Fig. 3: Different types of flower colour variability among 27 genotypes.

The winged bean genotypes exhibited a wide range of variation for seed yield per plant and other remaining characters studied. The results indicate that there is ample scope for selection of promising genotypes from present set of germplasm for seed yield and other characters improvement programme. The variability in this germplasm pool could be utilized in recombination breeding programme for accumulation of superior and desirable traits in a single genotype.

\section{Acknowledgement}

Author extends their gratitude and thanks to Prof. R. Nandan for providing his guide lines, as and when required. Due acknowledgment goes to Birsa agriculture university, Ranchi and Banaras Hindu University, Varanasi for providing genotypes of winged bean seeds. Banaras Hindu University is duly acknowledged for providing basic infrastructure facilities to carry out this research work.

\section{References}

Amoo, I.A., Adebayo, O.T. and Oyeleye, A.O. 2006. Chemical evaluation of Winged beans (Psophocarpus tetragonolobus), Pitanga cherries (Eugenia uniflora) and Orchid fruit (Orchid fruit myristica). Afr. J. Food Agric. Nutr. \& Dev., 6(2): 1-12. 
Chandel, K. P. S., and Pant, K. C. (1984). Winged bean in India, NBPGR Sci. Monogr. No. 8 pp. 1-30.

Chandel, P.R., Arora, R.K. and Pant, O.K.G. 1978a. Winged bean in India, its present status and prospects. The winged bean Proceedings, 1st International Symposium on developing the potential of winged bean, Manila, Phillippines. p. 393-395.

Khan, T. N. (1976). Papua New Guinea: A centre of genetic diversity in winged bean (Psophocarpus tetragonologus (L.) Dc.). Euphytica, 25(1), 693-705.

Mahto, C.S. and Dua, R.P. (2009): Genetic Divergence for Yield Contributing Traits in Winged Bean. Indian J. Plant Genet. Resour., 22(3): 239-242.

Mohamadali, A. and Madalageri, M. B. (2007). Analysis of genetic variability for seed yield and its component characters in winged bean [Psophocarpus tetragonolobus (L.) DC]. Legume Research, 30(4), 290-291. Mohanty, C. S., Verma, S., Singh, V., Khan, S., Gaur, P., Gupta, P., and Niranjan, A. (2013). Characterization of winged bean (Psophocarpus tetragonolobus (L.) DC.) based on molecular, chemical and physiological parameters. American Journal of Molecular Biology, 3(04), 187.

Nandan, R., Vaishnav, R. S., Srivastava, K., and Kumar, K. (2010). Genetic variability, heritability and genetic advance for yield components in winged bean (Psophocarpus tetragonalobus L.). Asian J. Bio Sci, 4(2), 298-299.
NAS, 1981. The Winged Bean: A HighProtein Crop for the Tropics. 2nd Ed. National Academy of Sciences. National Academy Press, Washington, D.C.

Philip, A. and Ramachandran, S.N. (1986): Genetic variability, heritability and genetic advance for some traits in winged bean. Veg. Sci., 13(1): 49-54.

Prasanth, K., Sreelathakumary, I., Celine, V. A., and Abdul Vahab, M. (2015). Evaluation and ranking of winged bean (Psophocarpus tetragonolobus (L.) DC.) Genotypes for enumerating available variability. International Journal, 3(11), 461-464.

Ray, S., Roychowdhury, R., and Tah, J. (2012). Genetic parameters and biochemical profiling of ten Psophocarpus tetragonolobus (L.) DC cultivars in tropical plains of West Bengal, India. World, 2(7), 71-75.

Seth, J.N., Misra, Y.K. and Lal, S.D. (1988): Genetic variability in winged bean (Psophocarpus tetragonolobus (L.) DC). Progressive Hort., 20(1-2): 7-10.

Singh, S.K., Singh, S.J. and Reemi Devi, N. (2013): The Winged Bean: A Vegetable Crop of Amazing Potential, Annals of Hort., 6(1): 159-160.

Singh, S.P. and Khanna, K.R. (1995): Genetic studies for yield and its components in winged bean (Psophocarpus tetragonolobus (L.) DC.). Proceedings of The National Academy of Sciences India Section B (biological Sciences). 65(4): 431-436.

\section{How to cite this article:}

Achal Kant and Rajeshwar Nandan. 2018. Performance and Variability Evaluation in Some Genotypes of Winged Bean [Psophocarpus tetragonolobus (L.) DC.]. Int.J.Curr.Microbiol.App.Sci. 7(05): 2104-2108. doi: https://doi.org/10.20546/ijcmas.2018.705.245 